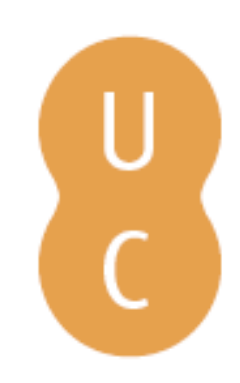

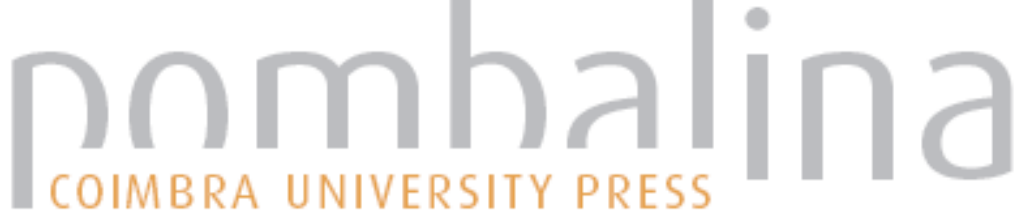

\section{Forest fire Preventing and Controlling Techniques in China}

Autor(es): $\quad$ Lifu, Shu; Yangguang; Hecheng; Xiaorui, Tian; Zhaofengjun; Mingyu,

Publicado por: Imprensa da Universidade de Coimbra

URL

persistente: URI:http://hdl.handle.net/10316.2/44570

DOI: $\quad$ DOI:https://doi.org/10.14195/978-989-26-16-506_53

Accessed : $\quad$ 26-Apr-2023 15:08:48

A navegação consulta e descarregamento dos títulos inseridos nas Bibliotecas Digitais UC Digitalis, UC Pombalina e UC Impactum, pressupõem a aceitação plena e sem reservas dos Termos e Condições de Uso destas Bibliotecas Digitais, disponíveis em https://digitalis.uc.pt/pt-pt/termos.

Conforme exposto nos referidos Termos e Condições de Uso, o descarregamento de títulos de acesso restrito requer uma licença válida de autorização devendo o utilizador aceder ao(s) documento(s) a partir de um endereço de IP da instituição detentora da supramencionada licença.

Ao utilizador é apenas permitido o descarregamento para uso pessoal, pelo que o emprego do(s) título(s) descarregado(s) para outro fim, designadamente comercial, carece de autorização do respetivo autor ou editor da obra.

Na medida em que todas as obras da UC Digitalis se encontram protegidas pelo Código do Direito de Autor e Direitos Conexos e demais legislação aplicável, toda a cópia, parcial ou total, deste documento, nos casos em que é legalmente admitida, deverá conter ou fazer-se acompanhar por este aviso.

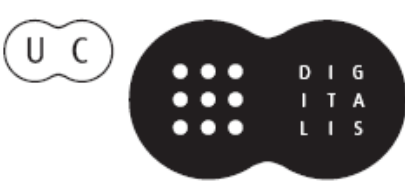




\section{ADVANCES IN}

\section{FOREST FIRE RESEARCH}

\section{8}

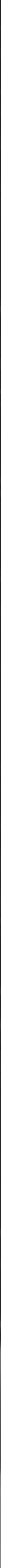




\title{
Forest fire Preventing and Controlling Techniques in China
}

\author{
Shu Lifu ${ }^{1 *}$, Yangguang2, Hecheng ${ }^{3}$, Tian Xiaorui ${ }^{1}$, Zhaofengjun ${ }^{1}$, Wang Mingyu ${ }^{1}$ \\ ${ }^{1}$ Institute of Forest Ecology, Environment \& Protection, Chinese Academy of Forestry (CAF) No.2 \\ Dongxiaofu, XiangYi Road, Haidian, Beijing, 100091, China. \\ \{slfhxk@126.com*;shulf@caf.ac.cn*\}. \\ ${ }^{2}$ School of Forestry, Northeast Forestry University, No.26, Hexing Road, Harbin,150040, \\ Heilongjiang province, China. \{yangguang@nefu.edu.cn\}. \\ ${ }^{3}$ Forest Fire Research Center, Nanjing Forest Police College, Nanjing, 210023, \\ China.\{hech_eng@163.com\}
}

\begin{abstract}
The area of China is large and the natural environment is very complex. The average forest cover of per person is very low. Planted and secondary forest account for much proportion of overall forest, and forest fire is very severe. The occurrence of forest fire is impacted by many factors, as the forest fire in China is impacted by inter-annual variability of weather and the regional distribution of fuel, the forest fire in China is characterized by distinct spatial and temporal distribution. The provinces that have more number and burned area concentrate on the Northeast and Southwest of China, and impacted by atmosphere current and seasonal monsoon, the fire season of the two regions have distinct seasonal variance. Human caused fires dominate the most parts of all the fires.Since 1987, the Chinese government attaches great importance to fire management. But there are still many fires occurrence in China every year. For the period 200-2009, the yearly average fires were 9493 , which caused burned areas 333796 ha. The yearly cost of fighting fires was 171220000 RMB (about 26341538 US\$). Human activities were mainly attributable to the forest fire, occupying more than 98\%. Most forest fires occurred in spring and autumn. Most fires occurred in southern China, accounting for $52 \%$ of the total each year, $37 \%$ in the southwest, $6 \%$ in northwest, and $4 \%$ in northeast and inner Mongolia, and $1 \%$ in other areas. It is expected the average temperature in northeastern China could increase $2.22^{\circ} \mathrm{C}$ in scenario $\mathrm{A} 2$ and $2.55^{\circ} \mathrm{C}$ in the $2040 \mathrm{~s}$ in scenario B2. That may cause the potential burned area will increase by an average 3\% and 20\% in 2040s under scenario A2 and B2, respectively. The fire season will prolong on average by five days and 18 days in the 2040s under scenario A2 and B2, respectively. Measures were made for reducing the fires, such as improving the organization system, fire equipments, strengthening fire monitoring and developing the fire research, ect.
\end{abstract}

Keywords: Fire prevention; China

\section{Introduction}

Fire plays an important role in forest ecosystem. After the great fires occurred in 1987 in northeastern China, the government pays more attention to the fire management. The fire agencies were founded in local government at all levels. The measures were made on fire prevention and extinguishment. From 1988 till now, statistics show that the average number of forest fire is 7,935, and the affected forest area is 92,000 hectares. Chinese government attaches great importance to forest cultivation and prevention, especially grasps the intensification of prevention of forest fire as an important measure of the construction of the ecological and forestry prevention.

\section{Causes of forest fires}

\subsection{Human's activities}

Most fires are due to man's fault while inappropriately using fires in production and daily life. According to statistical analysis for 2001-2010, human activities were mainly attributable to the forest 
fire, occupying more than 98\%. Take 2010 for instance, charcoaling, burning paper as sacrificial offerings, smoking in forest areas, or fires caused by children and the mentally handicapped account for $34.1 \%, 18.1 \%, 5.9 \%, 4.3 \%$, and $3.5 \%$ respectively. In Daxing'anling, northeastern China, the lightning fires accounted for about $30 \%$. In southwestern and southern China, many fire caused from prescribed fires in farmland. In Northeast China, hunter's casual smoking and cooking fires by medical herb pickers or mushroom pickers often cause forest fires.

\section{Fires distribution}

\subsection{Fire peak seasons}

The occurrence of forest fires in China showed two peaks in a year (Fig. 1). In northern China, the fire season includes two periods, which are spring (from March to June) and autumn (from September to November). But in southern China, most fire occurred in dry season (from November to next May). In general, there are two peaks of fire occurrences. For example, in 2005 the most fires occurred in April (4 604 ha, 40\%), and the most burned areas in October (128 662 ha, 40\%) (Fig 1).

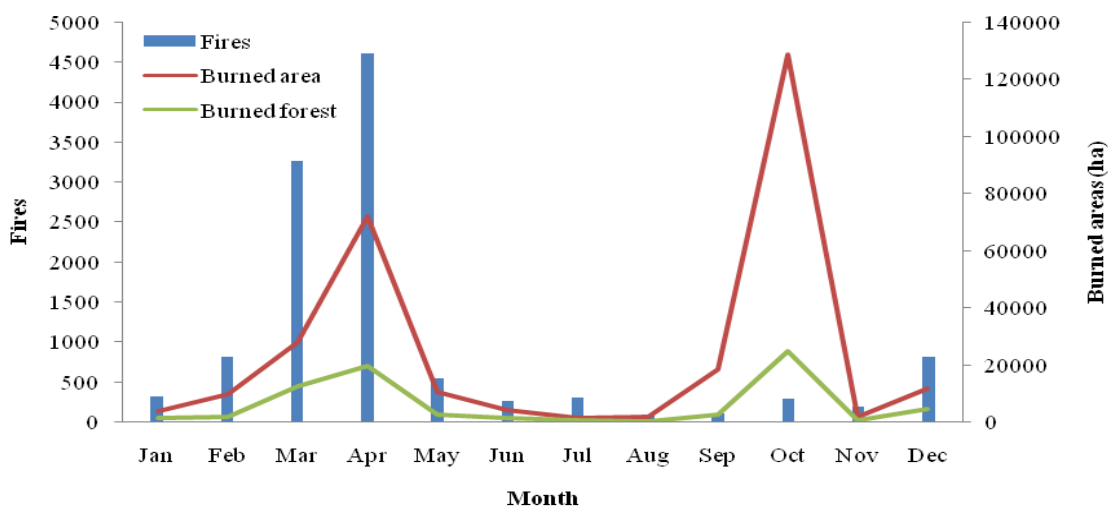

Figure 1 - Fire occurrence by month in 2005

\subsection{Regional distribution}

Most fires occurred in Southern forest, accounting for 52\% of the total each year, $37 \%$ in the southwest, $6 \%$ in northwest, and 4\% in northeast and inner Mongolia, and 1\% in other areas. For example, in 2005 the Hunan province had most fires (3,204 fires, accounted for $28 \%$ of the country) and Heilongjiang had most burned areas (132,248 ha, 46\%) and burned forests (24,307 ha, 33\%) (Fig. 2).

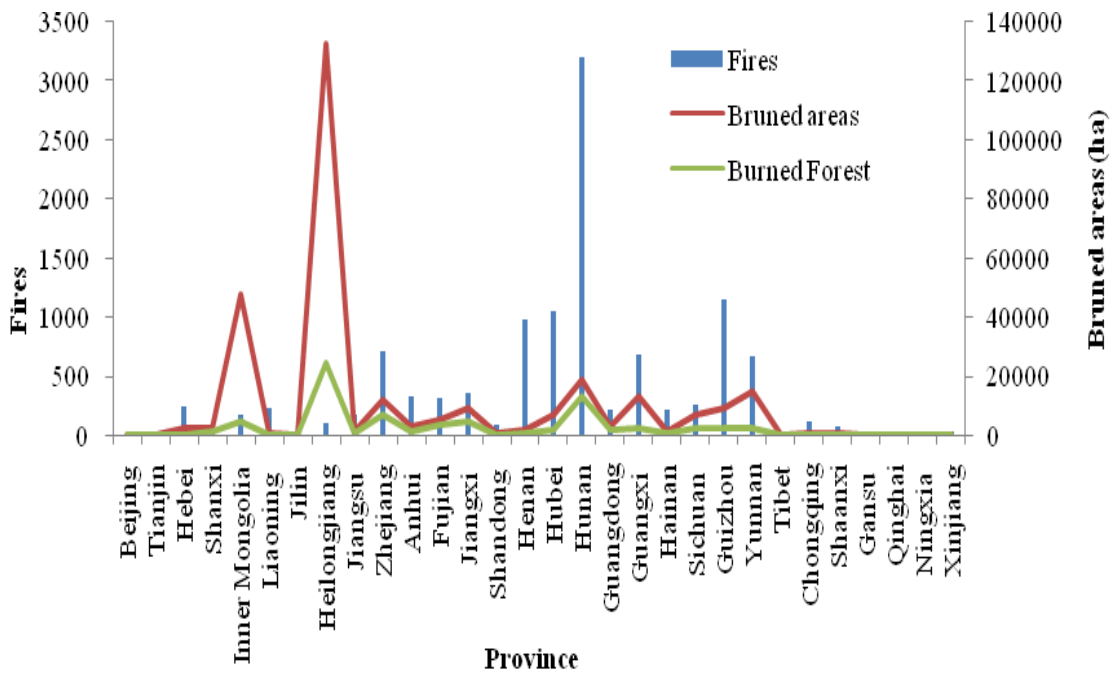

Figure 2 - Fire distribution in provinces in 2005 


\section{Recent fire situation}

For the period 200-2009, the yearly average fires was 9493 , in which fire alarm $(<1$ ha), average fire (1-100 ha), big fire (100-1000 ha) and conflagration (>1000 ha) were 5452 (57\%), 4014 (42\%), $23(0.2 \%)$ and $4(0.04 \%)$, respectively. The fires caused burned areas 333796 ha in each year, in which 138712 ha (42\%) was occupied by forests. In the period, the most burned areas occurred in 2003 (1 $123751 \mathrm{ha}$ ) and most fires (14 144) in 2008 (Fig 3).

The yearly cost of fighting fires was $171220000 \mathrm{RMB}$ (about 26341538 US\$), and brought the other losses 131257500 RMB (20 193460 US\$). Meanwhile, the wildfires caused 69 people died and 68 wounded in each year.

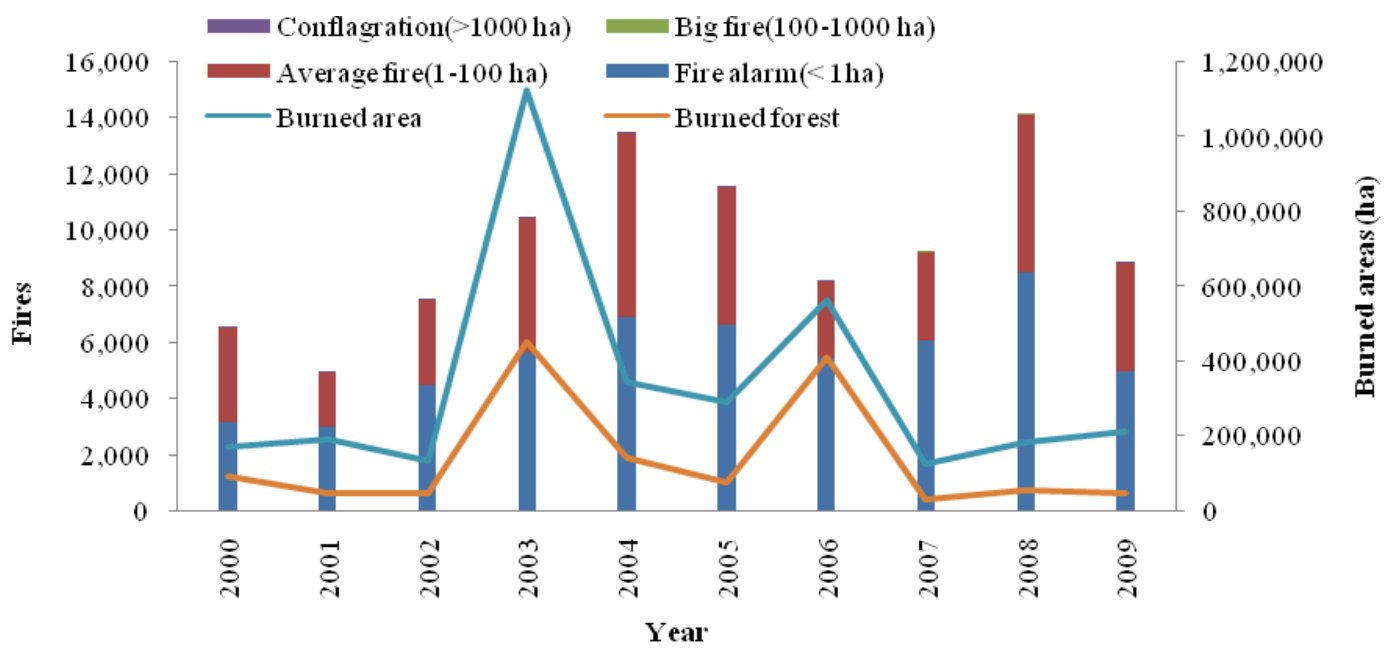

Figure 3 - Fire occurrence and burned area in China for 2000-2009

\section{Efforts to reduce the fires}

Effective measures are adopted to enhance the management of forest fire control, and minimize the number and losses of forest fires.

\subsection{Laws and regulations}

Since 2004, the Chinese central government has issued a series of documents, schemes, and regulations. Such as "Notification From the State Council on Further Implementing the Forest Fire Prevention", "State Emergency Preplan on Handling Particularly Serious Forest Fires", and "Forest Fire Regulations". These drafts and regulations greatly enhanced the scientificity and standardization of forest fire prevention career in China.

\subsection{Organization system}

At present, China government sets up the National Forest Fire Prevention office, which is composed of 19 member organizations. State council also holds meeting to deploy forest fire management. Officials of governments at all levels take their own responsibilities. Till 2010, 3326 forest fire command headquarters with 63,000 member staff and 3544 administrative offices with 20000 member staff have been built in China. There are fire agencies in the government at all levels.

\subsection{Fire sources management and education}

Fire sources were strictly controlled in key forest regions. Personals entering woodlands need to be checked and notified the fire sources management in the region. Billboards and posters are located in 
places. Broadcast, TVs, magazines, and networks were fully used to publicize the importance of forest fire prevention in key forest regions. So the public's awareness of the importance of fire prevention has been reinforced in past twenty years.

\subsection{Fire monitoring}

In China, the satellites and airplanes were used in fire detection except monitoring on the ground. There are 18 air bases in northeastern and southwestern China used in fire season. Each year more than 70 aircraft are rented, including more than 40 helicopters. Many satellites were used in fire season for fire detection, such as FY-1C, FY-1D, NOAA Series (NOAA-12, NOAA-14, NOAA-15, NOAA-16, NOAA-17) , EOS/MODIS (terra, aqua).

\subsection{Fire equipments}

There are 16,000 forest fire brigades in the whole country, which include 510,000 fire fighters. There also exists a forest armed police army (more than 10,000 in total). Since 2006, the central government has invested 2.6 billion RMB for fire prevention construction work. Over 200 projects were developed in key forest region to reduce the fire danger by using the comprehensive measures. So the infrastructures and facilities in high-risk environments and key point's areas are greatly improved. Funds on forest fire prevention and fighting are also included in the government budgets. Those were built of 16,000 fire watchtowers, 1,310,000 km highways, 1,190,000 km fire belts or fuel breaks. 63,000 special vehicles and 6700,000 fire machinery are equipped. There are 3 state-owned warehouses and 11,000 regional warehouses. More than 100 air-bombers are used in distinguishing fires in 15 provinces, flying more than 10,000 hours annually.

\subsection{Fire danger rating system}

A national fire danger rating system are founding and a net of fire weather stations will finish for better monitoring the fire danger. Some research projects are progressing on basic fire sciences and technologies application.

\subsection{Forest fire challenge}

It makes fire fighters further understand the nature of the forest fire.

In the past they thought their job was only to put out it once there is a fire, but now they have realized that it is more important than putting out the fire that they need to learn to manage the forest and then the fire. It shows that we have changed our strategy of fire fighting.

It improves the technology of forest fire forecast.

Though we haven't set up a fire forecast system around the whole country, we have started doing it in some areas of the country. And we have moved into a new stage of fire behavior prediction rather than the past metreological prediction of fire danger.

It raises the level of fire monitoring.

We have successfully built a network of fire monitoring through out the country. The network now has shown it significant effects. Plane's x-ray monitoring technology has been fully and widely adopted.

\subsection{Commanding fire fighting through information}

The transmission of message on forest fire must make it possible for fire fighters to get messages whenever and wherever they need. (for example when they are fighting the fire, when they want to prevent the fire or when they want to know how to use the fire safely). Especially as soon as defecting the fire, the message should be sent to the commanding center so that the center can arrange to send in time fire fighters and materials it needs to put out the fire to reduce the damage as much as possible. To achieve this, the message must be transmitted without stop between spots on land, between spots

Advances in Forest Fire Research 2018 - Page 492 
in the air, and between the air and the land. So we need to further the present system of communicative networks, at the same time we need to further develop the communicative technology in the fire field. We need to usse the short wave and ultra short wave to solve the communicative problems in the remote areas where message is difficult to reach.

\subsection{Fire extinguishers and fire fighting products}

It is not enough to have only scientific theories to prevent the forest fire. We need to have the advanced tools also. So we should not neglect the study of fire fighting facilities

\subsection{Isolating technology and the management of the burnable substances}

The management of the forest fire is not simply to prevent the fire passively but to actively prepared ourselves to prevent fire or to put out fire or even to use the fire through the technology of isolating the big fire and by managing the burnable substances. In future we need to do work in designing the fire preventing line and managing the forest by use fire.

\subsection{Fire fighters' training}

Knowing the importance of fire fighters' training is the basis to reduce the casualties and raise the efficiency of fire fighting. At present we badly need to strengthening our skill training of fire fighting and textbook compiling, and adding the number of our fire fighting facilities. In addition, we need to formulate our regulation of fire fighting training. In our training we need to use the multi-media resource, the computer network resource and some other facilities.

\section{Conclusion}

Although the government made great efforts on fire management, the serious fire situation is still a problem faced by the government. Most fires are caused by human activities. It is expected the average temperature will increase in most areas of China, and the potential burned area also increase in the future under the climate change scenarios. Measures should be made on fire prevention, monitoring, and fire fighting.

Forest fire management have make some progress in predicting and forecasting the forest fire causing weather, the cause of fire and fire behavior. Some works have done in the planned fire burning either inside or outside the forest.

Monitoring system is composed of the application of Meteorological satellites in monitoring and predicting forest fire and the application of distance satellites for emergency in communication.

In general forest fire study both at theoretical level and practical level, is mainly focused on the north part of the country while in other areas especially in the south and southwest areas has a relatively short history and backword.

\section{References}

Tian X.R., Shu L.F., Wang M.Y., Zhao F.J., Chen L.G. 2012A. The fire danger and fire regime for Daxing'anling region within 1987-2010. The 9th Asia-Oceania Symposium on Fire Science and Technology. Procedia Engineering, (in press)

Tian X.R., Douglas J.M., Jin J.Z., Shu L.F., Zhao F.J., Wang M.Y. 2011A, Wildfire and the Canadian forest fire weather index system for the Daxing'anling region of China. International Journal of Wildland Fire, 20, 963-973.

Tian X.R., Shu L.F., Zhao F.J., Wang M.Y. 2012B. Analysis of the conditions for lighting fire occurrence in Daxing'anling Region. Scientia Silvae Sinicae, 48(7): 96-103 (in Chinese) 
Zhao F.J., Shu L.F., Tiao X.R., Wang M.Y. 2009A. Change trends of forest fire danger in Yunnan Province in 1957-2007. Chinese Journal of Ecology, 28(11):2333-2338 (in Chinese)

Zhao F.J., Shu L.F., Di X.Y., Tian X.R., Wang M.Y. 2009B. Changes in the occurring date of forest fires in the Inner Mongolia Daixng'anling forest region under global warming. Scientia Silvae Sinicae, 45(6): 166-172 (in Chinese)

Zhao F.J., Shu L.F., Tian X.R., Wang M.Y. 2009C. The changes of forest fuel dryness conditions under global warming in Inner Mongolia Daixng'anling forest region. Acta Ecologica Sinica, 29(4): 1914-1920 (in Chinese)

Tian X.R., Shu L.F., Wang M.Y., Zhao F.J. 2011B. Forest fire danger ratings in the 2040s for northeastern China. Forestry Studies in China, 13(2): 85-96

Tian X.R., Shu L.F., Zhao F.J., Wang M.Y., Douglas J.M. 2011C. Future impacts of climate change on forest fire danger in northeastern China. Journal of Forestry Research, 22(3): 437-446

Tian X.R., Shu L.F., Zhao F.J., Wang M.Y. 2012C. Forest fire danger changes for southwest China under future scenarios. 48(1): 121-125 (in Chinese) 